\title{
Influence of Internet Finance on the Financing of Small and Medium-Sized Enterprises in China
}

\author{
Lingdong Zeng* \\ School of Economics and Trade, Guangdong University of Foreign Studies, Guangzhou 510006, Guangdong Province, \\ China \\ *Corresponding author: Lingdong Zeng, $1187109889 @$ qq.com

\begin{abstract}
Small and medium-sized enterprises greatly promote the economic progress and growth of national tax revenue as well as realize the escalation of career opportunities. However, as these enterprises are relatively small scale and have low capacity to face and resist risks in addition to China's flawed financial credit system, there are many difficulties faced by these enterprises in terms of financing to achieve their own development and progress. Recently, owing to the progress of internet information, especially the expansion of its application in the financial field, it has opened up a way for handling the financing difficulties faced by small and medium-sized enterprises. According to the specific financing situation of small and mediumsized enterprises in China, this study analyzes the impact of internet finance on the financing of small and medium-sized enterprises in China and formulates strategies to effectively deal with the financing difficulties of small and medium-sized enterprises in China, thus promoting the sustainable progress of small and medium-sized enterprises.
\end{abstract}

Keywords: Small and medium-sized enterprises; Financing; Internet finance; Strategy

Publication date: October 2021; Online publication: October 29, 2021

\section{Introduction}

Owing to the promotion of informatization in China, the traditional financial industry has begun to incorporate the internet. Internet payment tools and financial software have been used in more financial or non-financial enterprises. In the face of this situation, internet finance came into being. Due to the rapid progress of internet finance, the financing channels of small and medium-sized enterprises have become more diversified, dealing with the financing difficulties of small and medium-sized enterprises.

\section{Impact of internet finance on the financing of small and medium-sized enterprises in China}

Internet finance is a new financial mode, which closely connects modern information network technology with finance. Compared with traditional finance, it costs less and has higher work efficiency. In the financing activities of small and medium-sized enterprises in China, internet finance can help to alleviate their financing difficulties, reduce their financing pressure, and eventually promote the progress of these enterprises.

\subsection{Reduce information asymmetry}

In China, the rapid progress of the internet has promoted the progress of big data, cloud computing, as well as information and communication technology. These technologies have very wide communication range and prominent work efficiency, making it easier for users to obtain data and information. It is conducive to the development of system evaluation. Due to the continuous expansion of the application scope of big data technology, the capacity for information analysis and processing has been significantly improved to a 
certain extent. In the internet financing platform, through data, the financier, capital supplier, and macroeconomic situation can be scientifically analyzed, and the specific situation can be judged more objectively, so that the degree of information asymmetry can be reduced. As a result, it is possible to scientifically control the financing risk and formulate targeted countermeasures. For example, in the ecommerce financing mode, relying on e-commerce platforms and big data technology, it is possible to effectively process transactions, logistics, and other data information of financing enterprises, and then determine specific operations and credit evaluation. Tracking activities can also be carried out for the later use of funds, so as to promote the control of information asymmetry in the traditional financing mode ${ }^{[1]}$.

\subsection{Advantage in data analysis}

In the internet financing platform, big data analysis is one of its great functions. In terms of user behavior data, such as registration information, historical transaction data, transaction flow, etc., relevant collection and sorting activities can be carried out, and the psychological test system can be used to scientifically analyze customers' psychological activities in the form of model. The quantitative analysis of big data can also be used to evaluate specific business situations, credit ratings, and financial information of enterprises, so as to determine the risks existing in financial activities. Through the internet financial platform, both lenders and borrowers can be included. Through big data, it is possible to scientifically analyze the specific supply and demand situation, ensure the completion of classified activities of suppliers, develop matching work based on the analysis results, as well as allocate more appropriate groups to both parties, which would help to improve the financing speed and strengthen the financing efficiency of small and medium-sized enterprises ${ }^{[2]}$.

\subsection{Reduce financing costs}

In the internet financial platform, the intermediate links of financial activities can be omitted. Compared with traditional financial institutions, the financing cost of intermediate links can be reduced. For example, in the peer-to-peer $(\mathrm{P} 2 \mathrm{P})$ platform, the fund supplier can perform direct transaction activities with the fund demander to eliminate some financial intermediary links. In traditional finance, the procedure is very cumbersome, in which relevant qualifications need to be reviewed many times. Relying on internet finance and using relevant platforms, it is possible to ensure the rapid completion of docking activities between capital supply and demand. The capital arrival time of many platforms does not exceed 48 hours, realizing the reduction of time cost. Using big data analysis, it is also possible to establish a credit rating and risk management system, which can reduce labor costs.

\subsection{Realize personalized financing}

In internet finance, it is possible to fully use computer technology and artificial intelligence technology. Based on the business operating system, compared with traditional finance, it significantly improves the business processing speed and saves more time for customers. Exemplifying Alibaba's e-commerce loan, based on the prominent advantage of the internet, customer data information on the platform can be further processed and linked with external information. In this way, it can accurately determine customers information, improve financing efficiency, and standardize the credit risk. Affected by their own progress, the capital needs of small and medium-sized enterprises are relatively diversified. In internet finance, the development of various work mainly relies on computer technology to process business, which can promote the effective treatment of personalized needs. Using its data processing capability, it is possible to make independent identification of the needs of both parties and scientifically carry out matching activities, thus significantly enhancing the financing efficiency ${ }^{[3]}$. 


\section{Strategies for the financing of small and medium-sized enterprises in China}

In China, small and medium-sized enterprises play a vital role and greatly promote the progress of its national economy. However, if SMEs desire to achieve in-depth progress, they would have to face more problems. Among the many problems, the most prominent is financing difficulties. Diversified measures need to be formulated to ensure that this problem is handled properly.

\subsection{Improving enterprise organization and management}

Small and medium-sized enterprises in China have relatively low credit awareness; they do not recognize the significance of credit but only focus on immediate interests. Facing this situation, small and mediumsized enterprises in China should keep up with the pace of the times, vigorously develop relevant reform work, constantly improve the current system, and promote their comprehensive strength. With regard to internet finance, it is necessary to continue to develop learning activities to master more knowledge. Relevant measures should be taken to improve the information quality of enterprises and ensure that all tasks can be completed within the specified time. Relevant departments of enterprises should also focus on cultivating planning awareness, strengthening publicity activities, and establishing a good image. The subject of enterprise capital operation is cumbersome, highly professional, and technical. It has certain links with various aspects, including statistics, computer, management, market finance, and so on. Small and medium-sized enterprises need to pay close attention to the publicity and educational activities of financial knowledge, whereby they can carry out online financial knowledge competitions. In order to enhance the ability of employees in regard to internet financial work, the focus should be on training and educating on the operation of internet financial platform. In order to help employees master more advanced technologies, small and medium-sized enterprises can also develop in-depth communication activities with e-commerce companies for employees to accumulate more work experience.

\subsection{Strengthening financial management}

Compared with traditional financing applications, the restrictions in internet financing applications for loans are broader. This helps enterprises to reduce the cost of applying for loans. At this time, in order to strengthen the risk resistance of enterprises, it is necessary to further strengthen the management of small and medium-sized enterprises, especially their financial management. In regard to internet financing products, before deciding to carry out the application work, enterprises should reasonably formulate relevant plans and select more appropriate financing institutions as well as financing products in line with their own specific circumstances ${ }^{[4]}$. While selecting relevant products, enterprises should systematically consider their development needs, reduce all aspects of costs and expenses, as well as satisfy their capital needs. In order to avoid the impact on their credit image, small and medium-sized enterprises should formulate a financial management system and constantly improve the system, so as to provide a guarantee for the smooth progress of future financing activities.

\subsection{Establishing diversified financing mode}

Small and medium-sized enterprises in China have a single financing channel, and their financing activities mainly rely on banks and credit cooperatives. If small and medium-sized enterprises desire to achieve better development, they need more financing channels. The government should further strengthen credit guidance activities, promote the progress of financing financial products in a more diversified direction, and customize financial service products for small and medium-sized enterprises to better meet the needs of their progress. In inclusive finance and internet finance, small and medium-sized enterprises should be identified as key service objects, so as to greatly promote their progress. In China's banking industry, there 
are only a few small and medium-sized financial institutions, which requires the government to further strengthen the guiding role of credit policy, improve the approval business process of financial institutions, and increase the availability of loans to small and medium-sized enterprises.

\section{Conclusion}

In China, the proportion of small and medium-sized enterprises is extremely high. These enterprises play a vital role in the progress of the national economy. Through the internet financial mode, the financing difficulties of small and medium-sized enterprises can be handled efficiently. However, while developing specific countermeasures, there is a need to be fully aware of the risks of internet finance. Relevant departments should introduce policies and methods to perfect the relevant mechanisms, so as to provide a safer and harmonious financing environment to small and medium-sized enterprises as well as accelerate the long-term and stable progress of the socialist market economy.

\section{Disclosure statement}

The author declares that there is no conflict of interest.

\section{References}

[1] Wang G, 2020, Strategies to Solve the Long-Tail Problem of Internet Finance in the Financing of Small and Medium-Sized Enterprises - Taking Jiangsu Province as An Example. Accountant, (12): 11-12.

[2] Zhang Y, 2020, Research on the Financing Mode of China's Small and Medium-Sized Enterprises under the Internet Financial Environment. Lanzhou University of Finance and Economics.

[3] Feng Y, Yang J, Bai C, 2020, Impact of Internet Finance on the Financing of Small and Medium-Sized Enterprises and Countermeasures. Modern Marketing, (05): 38-39.

[4] Lin C, 2020, Research on the Impact of Internet Finance on the Financing of Small and Medium-Sized Enterprises. Public Investment Guide, (05): 128, 130. 